\title{
Nano-fluid viscosity screening and study of in situ foam pressure buildup at high-temperature high-pressure conditions
}

\author{
Mohammed Falalu Hamza ${ }^{1,2} \cdot$ Hassan Soleimani ${ }^{1,2} \cdot$ Zulkifli Merican Aljunid Merican $^{1,2,3}$. \\ Chandra Mohan Sinnathambi ${ }^{1,2} \cdot K$ arl Dunbar Stephen ${ }^{4} \cdot$ Abdelazeem Abbas Ahmad $^{2}$
}

Received: 22 April 2019 / Accepted: 31 July 2019 / Published online: 8 August 2019

(c) The Author(s) 2019

\begin{abstract}
In this study, an industrial-based surfactant known as MFomax surfactant has been modified with unfunctionalized and silanefunctionalized silica nanoparticles (NPs) to select the high viscous nano-fluid (NF) for generation of in situ foam to assess the differential pressure buildup $(\Delta p)$ behavior in the porous media. Different weight concentrations of NPs and MFomax from 0.1 to $0.5 \%$ were studied using Design Expert Software to generate full matrix design of NF formulations. The viscosity data were analyzed with the aid of response surface analytical tool to investigate the response of NPs loading on the NF viscosity for optimization. The microstructural properties of the NFs were characterized using spectroscopic equipment. Subsequently, the high viscous NF was selected to generate in situ foam in comparison with the precursor MFomax foam for $\Delta p$ buildup assessment at $110^{\circ} \mathrm{C}$ and $2023 \mathrm{psi}$ in the native reservoir core. Results have shown that both the silica NPs could significantly improve the MFomax viscosity; however, the silane-functionalized silica NPs have more effect to improve the viscosity and other microstructural properties than the unfunctionalized NPs, and thus, they were selected for further experimental studies. The coreflood $\Delta p$ buildup assessment shows that NF foam built more $\Delta p$ having average value of 46 psi against 25 psi observed in the case of the precursor MFomax foam. Thus, this study demonstrates that functionalized silica NPs could improve the MFomax viscosity and eventually generates high $\Delta p$ buildup at high-temperature high-pressure conditions.
\end{abstract}

Keywords Enhanced oil recovery $\cdot$ Viscosity $\cdot$ Gas mobility control $\cdot$ Nano-fluid $\cdot$ Foam

\section{Introduction}

The increasing energy demand for domestic and industrial uses led to the application of enhanced oil recovery (EOR) to extract residual oil after primary and secondary methods (Afolabi and Yusuf 2019; Hendraningrat and Torsæter 2016;

Hassan Soleimani

hassan.soleimani@utp.edu.my

$\triangle$ Zulkifli Merican Aljunid Merican

zulkifli.aljunid@utp.edu.my

1 Fundamental and Applied Sciences Department, UTP, 32610 Bandar Seri Iskandar, Perak Darul Ridzuan, Malaysia

2 Center of Research in Enhanced Oil Recovery, Institute of Hydrocarbon Recovery, UTP, 32610 Bandar Seri Iskandar, Perak Darul Ridzuan, Malaysia

3 Institute of Contaminant Management, Universiti Teknologi PETRONAS, 32610 Bandar Seri Iskandar, Perak, Malaysia

4 Institute of Petroleum Engineering, Heriot-Watt University, Edinburgh EH14 4AS, UK
Soleimani et al. 2016a, b; Hamza et al. 2017a, b). In most EOR technologies, such as surfactant flooding, polymer-surfactant flooding and foam flooding, surfactants play unprecedented roles that include reduction in interfacial tension and sometimes in gas mobility control (Moradi et al. 2019; Hanamertani et al. 2018; Dang et al. 2017; Kamal et al. 2017; Soleimani et al. 2015). A major technical challenge during chemical and gas flooding that received widespread interests is the effect of viscous fingering and early gas breakthrough (Jia et al. 2017; Xu et al. 2016; Hendraningrat and Zhang 2015). The major factor responsible for viscous fingering is viscosity difference between the injected chemical fluids and the crude oil (Fuseni et al. 2018; Jackson et al. 2017; Jamaloei et al. 2010, 2016). If the viscosity of the crude oil is greater than that of the injected chemical fluids, the chemicals create pathways (fingers) and by-pass the oil front (Nasr et al. 2019a, b). On the other hand, if the viscosity of crude oil is less than that of the injected chemicals, an efficient sweep and oil displacement would occur and eventually improve the oil recovery factor (Jamaloei et al. 2011). 
The severe cases of unfavorable mobility ratios may lead to early water (chemical) or gas breakthrough to production wells (Agi et al. 2018; Al Hinai 2017). High reservoir conditions such as high temperature in most cases contribute to these aforementioned factors, because the viscosity of the injected fluids decreases tremendously with temperature causing fingering to oil bank. This is the common problem injected chemical fluids face in the oil field. For decades, polymers are known as viscosity enhancer and have shown promising results, but present various challenges in oil field such as thermal instability, adsorption, gelation, high cost and environmental concern (Rellegadla et al. 2017; Speight 2016). However, recent EOR studies focus on nanoparticles (NPs) utilization to improve important properties such as interfacial tension, wettability alteration and viscosity due to their thermophysical properties (Koca et al. 2017; Adenutsi et al. 2018; Zallaghi et al. 2018; Sharma and Sangwai 2017; Choi et al. 2017; Kean Chuan et al. 2016; Cheraghian et al. 2015; Pozhar 2000; Hendraningrat et al. 2013). Worthen et al. (2013) describe the advantage of NPs in surfactant blends for their ability to be irreversibly adsorbed at interface and provide potential benefits to surfactant's properties. Similarly, Ahmadi and Shadizadeh (2013) studied the adsorption behavior of surfactant in the presence of NPs onto sandstone rock. The authors believed that NPs could significantly inhibit the surfactant adsorption. Because of these advantages, researchers have become more interested to functionalize the surface of NPs to improve properties of the NFs. The study of Zhang et al. (2011) pointed out the benefit of NPs surface coating tailored to achieve certain additional properties that could withstand the effect of high temperature. Agista et al. (2018) also provide a comprehensive review on the state of the art of NPs application in EOR. The authors summarized different functionalized NPs, particularly $\mathrm{SiO}_{2} \mathrm{NPs}$, to achieve various influential factors in nano-stabilized foam. To this effect, Azarshin et al. (2017) experimentally investigated the effect of silane-modified $\mathrm{SiO}_{2}$ NPs in waterflood injection scenario and concluded by applauding the role of surface coating to influence the IFT and contact angle and ultimately increased oil production by $18 \%$ relative to uncoated NPs. Similarly, Al Yousef et al. $(2017,2019)$ in their foam stabilization experiment using surface-functionalized NPs found out that functionalized NPs have the ability to decrease gas mobility. The NPs/NF could be a suitable candidate to improve various properties; consequently, the application of NPs with emphasis on the modified materials has still remained the subject of discussion for the purpose of increasing hydrocarbon recovery. The present study seeks to investigate the modification of industrial-based surfactant known as MFomax surfactant with unfunctionalized and silane-functionalized silica NPs to select the high viscous NF for the generation of in situ foam to assess the $\Delta p$ buildup behavior in the porous media.

The $\Delta p$ buildup serves as a prerequisite for increasing oil production. The full matrix design of the NF formulations is achieved using design of experiment expert software (DOE version 8.0.0). The software has a collection of analytical tools that is systematically used in determining the causeand-effect relationships between input parameters (NPs and surfactant) to optimize the output (viscosity). The tools can be used to understand the synergistic or antagonistic responses of the input parameters on the output through response surface methodology (RSM). It also allows the development of regressional models that could give information on the quantitative contributions of the input parameters to output (Azarshin et al. 2017).

\section{Materials and methods}

The unfunctionalized and silane-functionalized $\mathrm{SiO}_{2} \mathrm{NPs}$ (functionalized with 3-4 wt\% of 3-aminopropyltriethoxysilane coupling agent-KH55O) were purchased from US Research Nanomaterials, Inc., USA. The particles have average diameters of $20-30 \mathrm{~nm}$, surface area of $180-600 \mathrm{~m}^{2} / \mathrm{g}$, bulk and true density of $<0.10$ and $2.4 \mathrm{~g} / \mathrm{cm}^{3}$, respectively. The chemical surfactant (MFomax) with $20 \%$ active content is an in-house-developed surfactant formulated from the mixture of anionic and amphoteric surfactants, supplied by PETRONAS Research Sdn, Bhd. (PRSB), Malaysia. This surfactant is selected for the reason that blends of different charged surfactants are preferable for achieving various important properties due to synergy action (Hakiki et al. 2015; Memon et al. 2017). The properties of native reservoir core sample sourced from Malaysian oil field are presented in Table 1. All materials and chemicals were used as received without further treatment.

\section{Nano-fluid chemical formulation}

Table 2 shows the full matrix factorial design generated with the aid of DOE to formulate the NFs. The table presents 20 random experimental formulations of NFs performed for each of the NPs with six central formulations (NF 15-20) to serve as replicates to minimize error. The brine sample

Table 1 Properties of native reservoir core analyzed

\begin{tabular}{ll}
\hline Core properties & \\
Pore volume PV (cc) & 15.60 \\
Porosity $\emptyset(\%)$ & 23.10 \\
Permeability $K_{\text {air }}(\mathrm{mD})$ & 198.6 \\
Length $(\mathrm{mm})$ & 61.10 \\
Diameter (mm) & 37.50 \\
Mass (g) & 138.0 \\
Sampling depth (ft) & 6173 \\
\hline
\end{tabular}


Table 2 Full matrix design of the NFs showing the concentrations of the NPs and MFomax used in each formulation and analyzed at different aging times

\begin{tabular}{lllc}
\hline Nano-fluid & MFomax $(\%)$ & ${ }^{a}$ NPs $(\%)$ & Aging (days) \\
\hline NF11 & 0.3 & 0.1 & 9 \\
NF04 & 0.4 & 0.4 & 6 \\
NF07 & 0.2 & 0.4 & 12 \\
NF02 & 0.4 & 0.2 & 6 \\
NF08 & 0.4 & 0.4 & 12 \\
NF16 & 0.3 & 0.3 & 9 \\
NF15 & 0.3 & 0.3 & 9 \\
NF09 & 0.1 & 0.3 & 9 \\
NF05 & 0.2 & 0.2 & 12 \\
NF13 & 0.3 & 0.3 & 3 \\
NF06 & 0.4 & 0.2 & 12 \\
NF17 & 0.3 & 0.3 & 9 \\
NF01 & 0.2 & 0.2 & 6 \\
NF18 & 0.3 & 0.3 & 9 \\
NF03 & 0.2 & 0.4 & 6 \\
NF20 & 0.3 & 0.3 & 9 \\
NF19 & 0.3 & 0.3 & 9 \\
NF14 & 0.3 & 0.3 & 15 \\
NF12 & 0.3 & 0.5 & 9 \\
NF10 & 0.5 & 0.3 & 9 \\
\hline
\end{tabular}

${ }^{a} \mathrm{NPs}$ represent each uncoated and coated $\mathrm{SiO}_{2} \mathrm{NPs}$. This means that the full matrix design in the table is used for each size of NPs separately

(3.5 wt \%) used in the NFs formulations was prepared based on the composition of Malaysian oil field formation water (composed of $\mathrm{NaCl}, \mathrm{KCl}, \mathrm{MgCl}_{2} \cdot 6 \mathrm{H}_{2} \mathrm{O}, \mathrm{CaCl}_{2} \cdot 2 \mathrm{H}_{2} \mathrm{O}$, $\mathrm{Na}_{2} \mathrm{SO}_{4}, \mathrm{NaHCO}_{3}, \mathrm{SrCl}_{2} \cdot 2 \mathrm{H}_{2} \mathrm{O}$ ). Each NFs formulation was stirred at $25{ }^{\circ} \mathrm{C}$ for $12 \mathrm{~h}$ using a magnetic stirrer (IKACMAG HS 7 S002) and sonicated with ultrasonic bath device (Ultrasonics Corporation, USA) at $25 \mathrm{~Hz}$ for $1 \mathrm{~h}$ to minimize particles aggregations in the NFs.

\section{Viscosity measurement and optimization}

The resistance of fluids to flow is termed as a viscosity which is one of the most important rheological properties governing the performance of foaming agents in the reservoir. The choice of high viscous fluid in the screening of NFs is important for the generation of good-quality foam. The dynamic viscosity measurements of the NFs (MFo$\max / \mathrm{SiO}_{2}$ and $\mathrm{MFomax} / \mathrm{SiO}_{2}-\mathrm{KH} 550 \mathrm{NFs}$ ) were conducted using Anton Paar Modular Compact Rheometer (MCR 302) at $90{ }^{\circ} \mathrm{C}$. The analysis of variance (ANOVA) was used to statistically analyze the viscosity data obtained for optimization studies. The analyzed data were examined to see the interaction effects by multiple regressions to develop multivariate models. Thereafter, the high viscous NF was further analyzed with high-temperature high-pressure electromagnetic viscometer (Vinci Technologies, HTHP EV 1000) at $125^{\circ} \mathrm{C}$ and 2023 psi to observe the viscosity behavior typical to reservoir conditions.

\section{Characterization study}

The chemical properties and surface morphology of the NFs were characterized using different spectroscopic instruments as follows.

\section{Dynamic light scattering}

Dynamic light scattering (DTL) measurement of the dispersion of NFs was performed using particle size analyzer (DT 1202) to ascertain the aggregation and size distribution of the dispersed NPs in the mixtures. Prior to analysis, the NF was homogenized using the sonication device. Thereafter, about $15 \mathrm{ml}$ of the NF sample was placed in the measuring chamber which is equipped with a detector sensor to measure the particle's Brownian motions at $25^{\circ} \mathrm{C}$, from which the average size and distributions were analyzed.

\section{FTIR spectroscopy}

Fourier-transform infrared spectroscopy (FTIR) (PerkinElmer Spectrum ISO AKX1300573 Nexus FTIR) was used to study the chemical interactions between the MFomax and the NPs by comparing their spectral absorptions before and after the chemical formulation. The transmittance was measured against the wave number between 600 and $4000 \mathrm{~cm}^{-1}$.

\section{X-ray diffraction}

The X-ray diffraction (XRD Bruker D2 Phaser) analysis was performed using $\mathrm{Cu} \mathrm{K} \alpha$ radiation at $40 \mathrm{kV}$ and $40 \mathrm{~mA}$. All scans were classically accomplished over a $2 \theta$ range from $10^{\circ}$ to $99^{\circ}$ at a $0.02 / \mathrm{s}$ speed, with an opening slit, an antiscatter slit and a receiving slit of $2 \mathrm{~mm}, 6 \mathrm{~mm}$ and $0.2 \mathrm{~mm}$, respectively.

\section{FESEM spectroscopy}

Field emission scanning electron micrograph (FESEM Carl Zeiss AG SUPRA 55VP) instrument was used to study the nanocomposite morphology through which the physical morphological transformation was assessed. The sample was coated with gold to minimize charge reflection due to NPs to give proper viewing at different magnifications from 100 to $100,000 \times$.

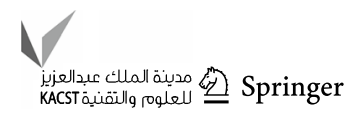




\section{Thermogravimetric analysis}

Thermogravimetric analysis (TGA) instrument (PerkinElmer Pyris 1) equipped with aluminum pans was used to investigate the thermal stability of the NF. Measurements were carried out under air atmosphere and a controlled temperature program which automatically maintains constant temperature during thermal decompositions. About 8-10 mg sample mass was heated, and the weight loss measurement was carried out between 25 and $180^{\circ} \mathrm{C}$ at a heating rate of $10{ }^{\circ} \mathrm{C} \mathrm{min}{ }^{-1}$.

\section{Coreflood experiment: in situ foam generation and $\Delta p$ buildup assessment}

Multifluid core displacement equipment (Sanchez coreflood V1.5740) presented in Fig. 1 is used to generate in situ foam for $(\Delta p)$ buildup assessment. The system consists of three separate chambers of oil, brine and chemical, as well as a gas accumulator, and a cell used for confined pressure which housed a core holder. The core holder is supported by the injections and receiving ends, within which the injection and outlet pressures are detected. The whole system is connected to a computer to monitor the $\Delta p$ buildup at defined experimental conditions. A manual saturator was used to saturate the core with the brine under $1000 \mathrm{psi}$ pressure for $24 \mathrm{~h}$ prior to installment inside the core holder. The experimental conditions used to study the $\Delta p$ across the core are presented in Table 3.

Several pore volumes (PV) of brine are injected at $0.2 \mathrm{cc} \mathrm{ml}^{-1}$ flow rate to record the $\Delta p$ buildup due to waterflood. After the $\Delta p$ stabilizes, 1.1 PV of the nitrogen gas $\left(\mathrm{N}_{2}\right)$ was injected into the brine by maintaining $0.2 \mathrm{cc} \mathrm{ml}^{-1}$ flow rate until no further displacement of the brine was observed. At this stage, the $\Delta p$ buildup due to gas injection was also observed. A few more PV of brine was re-injected until the $\Delta p$ reached steady state. Several PV of MFomax surfactant were injected by maintaining the same flow rate
Table 3 Coreflood test conditions used to study $(\Delta p)$ buildup

\begin{tabular}{ll}
\hline Coreflood test parameters & \\
Flow rate $\left(\mathrm{cc} \mathrm{min}^{-1}\right)$ & 0.2 \\
Gas type & $\mathrm{N}_{2}$ \\
Test temperature $\left({ }^{\circ} \mathrm{C}\right)$ & 110 \\
Injection pressure (psi) & 2023 \\
Overburden pressure (Psi) & 3023 \\
Conc. of surfactant (v \%) & 0.4 \\
Conc. of functionalized NPs (wt\%) & 0.5 \\
Brine (wt\%) & 3.5 \\
\hline
\end{tabular}

to ensure full core saturation with the MFomax. Thereafter, another minimum of $5 \mathrm{PV}$ of the $\mathrm{N}_{2}$ gas was injected at the same flow rate to generate in situ MFomax foam and the $\Delta p$ buildup due to MFomax foam was also observed. This procedure was repeated for foam generation using NF (MFomax/SiO $2-\mathrm{KH} 550 \mathrm{NPs}$ ), and $\Delta p$ buildup by NF was also recorded. All the data recorded were carefully analyzed to assess the $\Delta p$ buildup relative to $\mathrm{PV}$ of different slug injections. The permeability $(K)$ impairment due to NPs was examined relative to pre- and post-NF injection using the expression given in Hendraningrat et al. (2013).

\section{Results and discussion}

\section{Rheology studies}

The ANOVA of the NFs viscosity is presented in Table 4. From the table, all the data in each case were in reasonable agreement because the observed $p$ values are less than 0.05 with good $R^{2}$ near 1.0. Real statistical data are recognized based on $p$ and $R^{2}$ values, and good data must have a strong confidence interval $(>90 \%)$ at $p<0.05$ for the model to be significant and the lack of fit not significant, respectively (Almeida et al. 2017). The interaction effects of MFomax ${ }^{*}$ aging $^{2}$ and aging ${ }^{3}$ in the MFo$\max / \mathrm{SiO}_{2} \mathrm{NF}$ are not significant $(p>0.05)$ after reducing the model to eliminate the non-significant terms; therefore, they

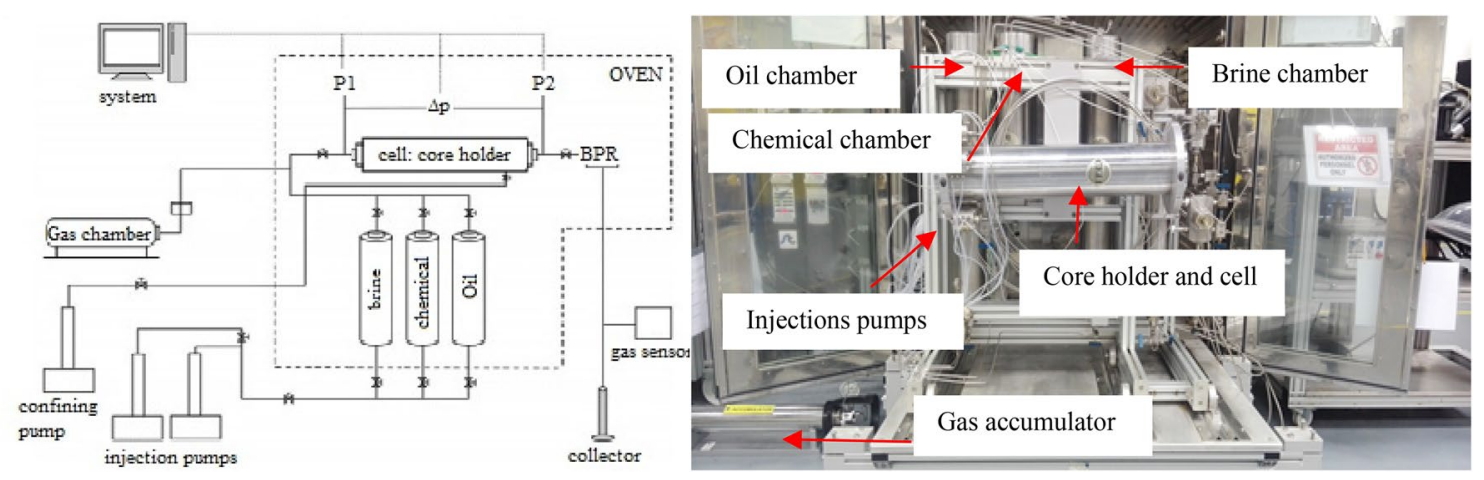

Fig. 1 Schematic diagram and image of the high-temperature high-pressure coreflood displacement equipment used

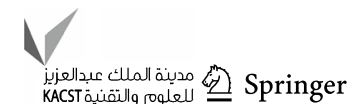


Table 4 Statistical data and analysis of variance (ANOVA) for viscosity of the NF

\begin{tabular}{|c|c|c|c|c|c|c|c|c|c|}
\hline Viscosity response & Factors & Mean & SD & $R^{2}$ & $R^{2} \mathrm{Adj}$. & $R^{2}$ Pred. & $F$ value & $p<0.005$ & \\
\hline \multirow[t]{12}{*}{ MFomax $/ \mathrm{SiO}_{2}$} & Cubic model & 0.62 & 0.02 & 0.99 & 0.98 & 0.94 & 82.18 & 0.0001 & significant \\
\hline & MFomax & & & & & & 10.58 & 0.0100 & \\
\hline & $\mathrm{SiO}_{2}$ & & & & & & 109.7 & 0.0001 & \\
\hline & MFomax* $\mathrm{SiO}_{2}$ & & & & & & 11.20 & 0.0086 & \\
\hline & $\mathrm{SiO}_{2} *$ aging & & & & & & 92.63 & 0.0001 & \\
\hline & $\mathrm{SiO}_{2}^{2}$ & & & & & & 23.57 & 0.0009 & \\
\hline & Aging $^{2}$ & & & & & & 87.00 & 0.0001 & \\
\hline & MFomax $^{2 *} \mathrm{SiO}_{2}$ & & & & & & 17.95 & 0.0022 & \\
\hline & MFomax $^{2} *$ aging & & & & & & 114.2 & 0.0001 & \\
\hline & MFomax*aging $^{2}$ & & & & & & 0.190 & 0.6755 & \\
\hline & Aging $^{3}$ & & & & & & 2.640 & 0.1384 & \\
\hline & Lack of fit & & & & & & 1.590 & 0.3078 & not significant \\
\hline \multirow[t]{6}{*}{$\mathrm{MFomax} / \mathrm{SiO}_{2}-\mathrm{KH} 550$} & Cubic model & 0.75 & 0.10 & 0.92 & 0.90 & 0.62 & 44.15 & 0.0001 & significant \\
\hline & $\mathrm{SiO}_{2}-\mathrm{KH} 550$ & & & & & & 117.6 & 0.0001 & \\
\hline & $\mathrm{SiO}_{2}-\mathrm{KH} 550^{2}$ & & & & & & 22.72 & 0.0002 & \\
\hline & Aging $^{2}$ & & & & & & 11.51 & 0.0040 & \\
\hline & $\mathrm{MFomax}^{2} * \mathrm{SiO}_{2}-\mathrm{KH} 550$ & & & & & & 28.28 & 0.0001 & \\
\hline & Lack of fit & & & & & & 2.860 & 0.1288 & not significant \\
\hline
\end{tabular}

could be ignored. Based on these statistical data, the experimental data against the predicted data presented in Fig. 2a, b matched with the preference line with $R^{2}$ above 0.9 indicating good agreement. These best fit with the cubic models shown in Eqs. (1) and (2) that described the synergistic and antagonistic relationships between the MFomax and NPs on the NF's viscosity. The coefficient factors in the model quantified the extent to which both the MFomax and NPs influence the NF's viscosity in synergistic and antagonistic relationships. Thus, from the equations, the $\mathrm{SiO}_{2}-\mathrm{KH} 550 \mathrm{NPs}$ had greater synergistic interaction $(+0.31)$ with the MFomax than the $\mathrm{SiO}_{2}$ NPs (+0.04). In addition, in terms of independence effect, the

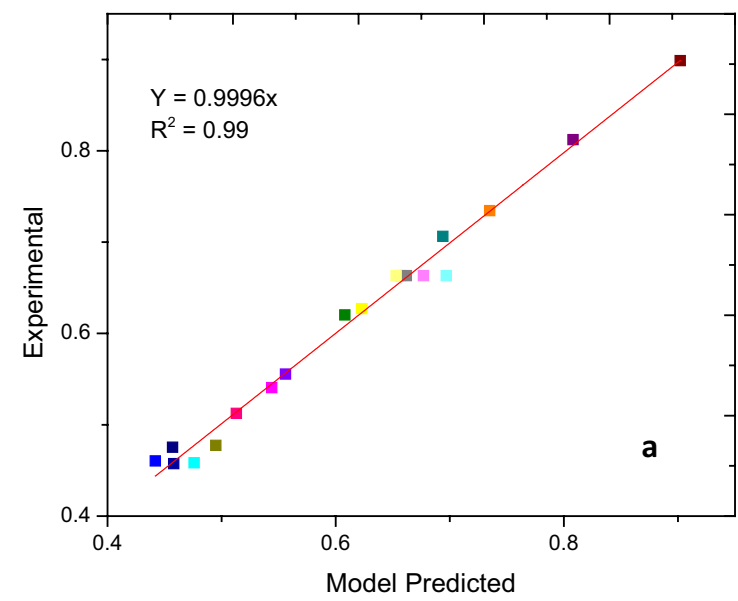

$\mathrm{SiO}_{2}-\mathrm{KH} 550 \mathrm{NPs}$ had a more influential effect $(+0.48)$ than the $\mathrm{SiO}_{2} \mathrm{NPs}(+0.082)$ on the viscosity. Therefore, the NPs functionalized with the KH550 have a more significant effect to increase the viscosity of MFomax surfactant than unfunctionalized NPs.

$$
\begin{aligned}
\operatorname{Viscosity}_{\left(\mathrm{MFomax}_{\mathrm{SiO}}\right)}= & +0.66+0.026 * \mathrm{MFomax} \\
& +0.082 * \mathrm{SiO}_{2}+0.022 * \mathrm{MFomax} \\
& * \mathrm{SiO}_{2}+0.064 * \mathrm{SiO}_{2} * \text { aging } \\
& -0.024 * \mathrm{SiO}_{2}^{2}-0.046 * \operatorname{aging}^{2} \\
& +0.044 * \mathrm{MFomax}^{2} * \mathrm{SiO}_{2}+0.077 \\
& * \mathrm{MFomax}^{2} * \text { aging }-0.0044 * \text { MFomax } \\
& * \operatorname{aging}^{2}-0.0045 * \text { aging }^{3}
\end{aligned}
$$

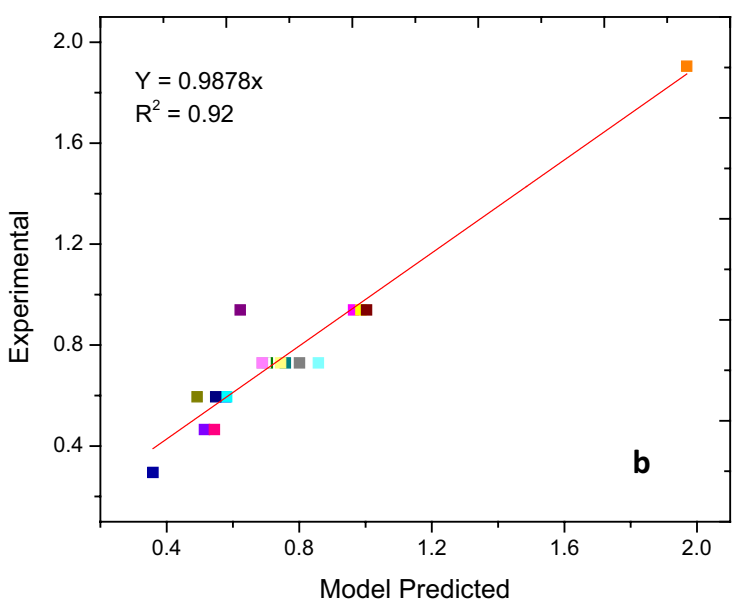

Fig. 2 Comparison between experimental and the model predicted data of a MFomax/SiO $2 \mathrm{NF}$ and $\mathbf{b} \mathrm{MFomax} / \mathrm{SiO}_{2}-\mathrm{KH} 550$ 
Viscosity $_{\left(\mathrm{MFomax} / \mathrm{SiO}_{2}-\mathrm{KH} 550\right)}=+0.73+0.48 * \mathrm{SiO}_{2}$

$$
\begin{aligned}
& -\mathrm{KH} 550+0.13 * \mathrm{SiO}_{2} \\
& -\mathrm{KH} 550^{2}-0.093 * \text { aging }^{2} \\
& -0.31 * \mathrm{MFomax}^{2} * \mathrm{SiO}_{2}-\mathrm{KH} 550
\end{aligned}
$$

The effects of NPs loading on the MFomax are demonstrated in the three-dimensional surface plots (Fig. 3a, b). From 3a, it can be observed that, by keeping the MFomax concentration constant, increasing the concentration of $\mathrm{SiO}_{2}$ NPs tends to increase the NF's viscosity. While, at a constant $\mathrm{SiO}_{2}$ NPs concentration, the increase in the MFomax results in an initial increase in the viscosity, and when the MFomax was gradually increased, the viscosity decreases. Similarly, when $\mathrm{SiO}_{2}-\mathrm{KH} 550$ NPs loading at a constant MFomax is increased, the NF's viscosity increases. However, at a constant $\mathrm{SiO}_{2}-\mathrm{KH} 550$, the viscosity decreased and later increased with increasing MFomax. Thus, in both the cases, the influence of the NPs on the NF's viscosities had been demonstrated.

Figure $4 \mathrm{a}, \mathrm{b}$ demonstrates the viscosity behavior of each NF with aging time (2 weeks). From the results (4a), the viscosity of the MFomax $/ \mathrm{SiO}_{2}$ decreased with aging time, while for the $\mathrm{MFomax} / \mathrm{SiO}_{2}-\mathrm{KH} 550$ (4b) the aging time has less effect on the viscosity of the NF due to no significant changes observed along the aging axis. This explains the influence of the coating agent (KH550).

Therefore, the optimized formulation ratios for both the MFomax/SiO 2 and $\mathrm{MFomax} / \mathrm{SiO}_{2}-\mathrm{KH} 550 \mathrm{NFs}$ were found
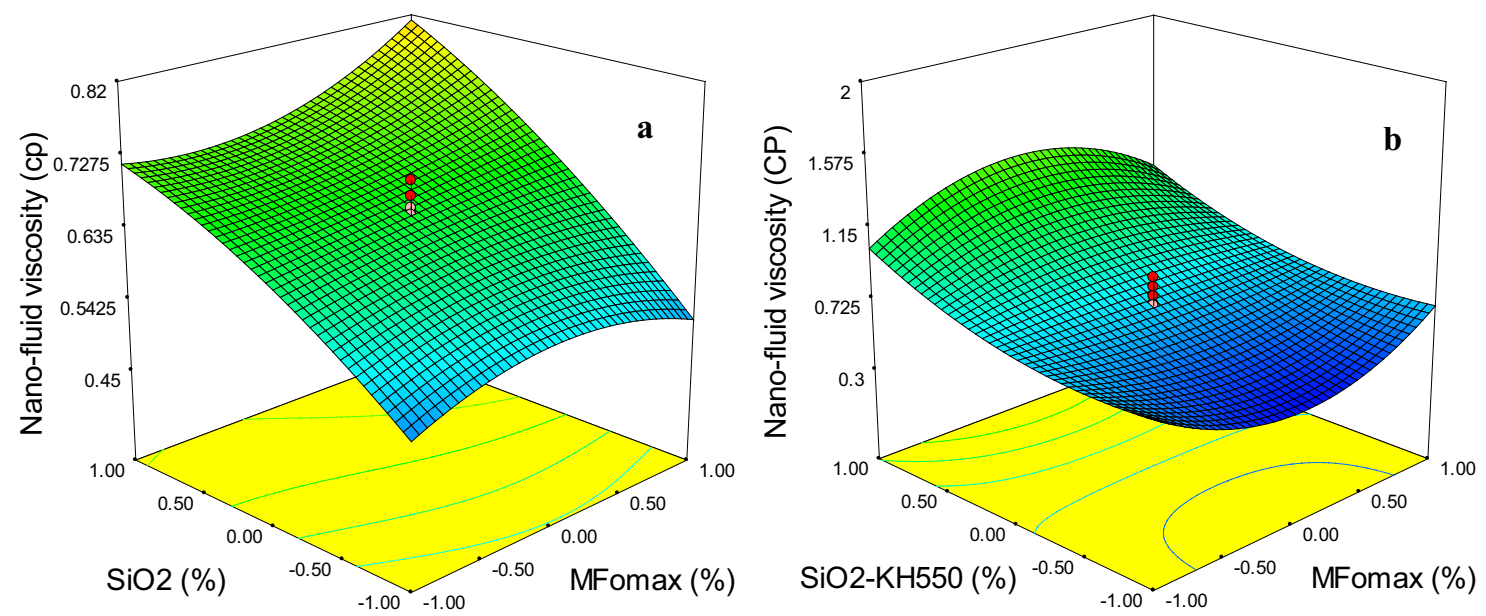

Fig. 3 Effect of NPs loading on the NF's viscosity; the $\mathrm{x}$ axis represents the concentrations presented in terms of the coded value which indicate the lowest value to be $0.1 \%(-1)$ and the highest $0.5 \%(1.0)$
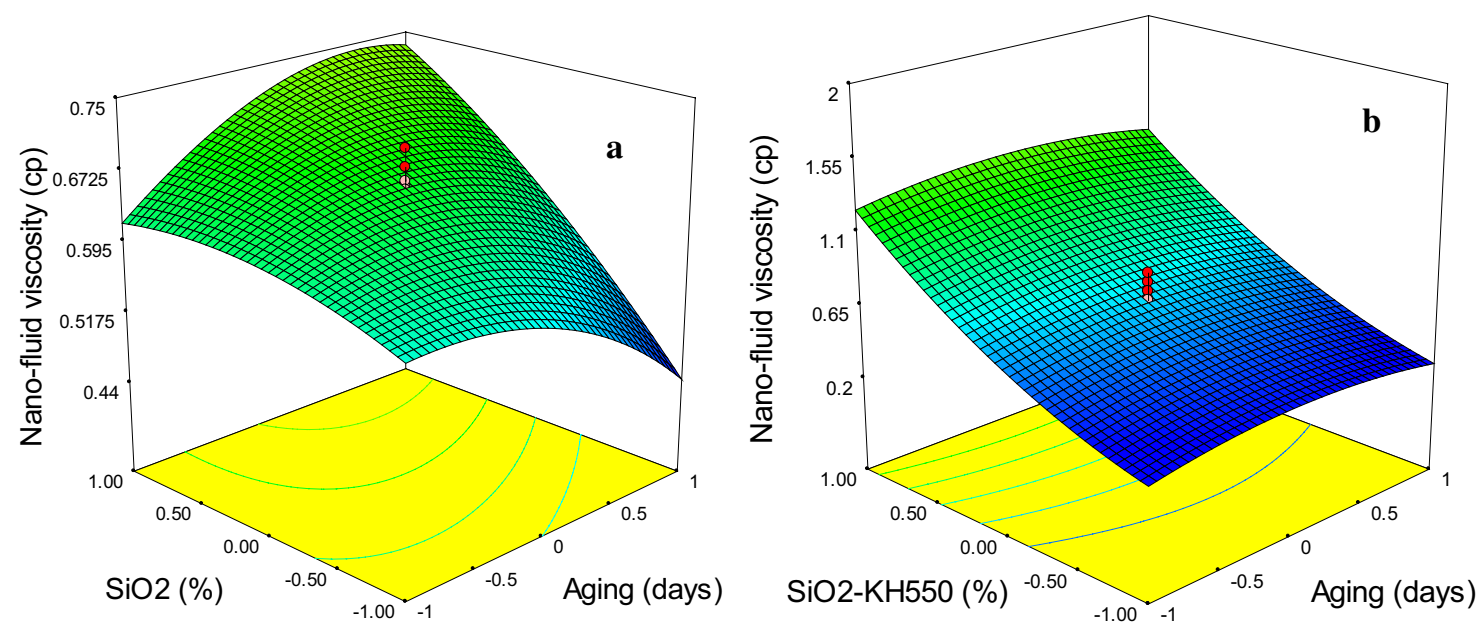

Fig. 4 Effect of aging time on the NF's viscosity with the axis of $\mathrm{SiO}_{2}$ and $\mathrm{SiO}_{2}-\mathrm{KH} 550$ represents concentration presented in terms of the coded value which indicate the lowest value to be $0.1 \%(-1)$ and the highest $0.5 \%(1.0)$, while for aging is the number of days from $3(-1)$ to $15(1.0)$ 
to be $0.4: 0.4 \%$ and $0.4: 0.5 \%$, respectively, and these were used for further characterizations and analysis.

\section{Particle aggregation in the NF}

The particle size distributions of the dispersion of the NPs in the MFomax surfactant are shown in Fig. 5a, b. From the figure, it can be seen that NPs aggregated in the MFomax compared to the respective initial sizes of 20-30 nm before the dispersion. However, about $90 \%$ of the NPs in MFomax/ $\mathrm{SiO}_{2}-\mathrm{KH} 550 \mathrm{NF}$ are within the nano-scale $(<100 \mathrm{~nm})$ indicating minimal aggregation, contrary to $\mathrm{MFomax} / \mathrm{SiO}_{2} \mathrm{NF}$. This observation is mainly due to the surface functionalization properties of NPs in the $\mathrm{MFomax} / \mathrm{SiO}_{2}-\mathrm{KH} 550 \mathrm{NF}$, making particles get separated from one another resulting in minimal aggregation in the surfactant medium (Susheel 2015).

\section{Influence of temperature and pressure on the NF's viscosity}

Figure 6 shows the effect of temperature on the NFs viscosity ramped from 30 to $100{ }^{\circ} \mathrm{C}$. From the figure, it can be seen that both the NFs exhibited higher viscosity than the free-MFomax at ambient and higher temperatures; this shows that NPs loading could improve the viscosity of the MFomax because of NPs thermophysical properties (Protsak et al. 2018; Xu et al. 2015). However, the NF viscosity containing $\mathrm{SiO}_{2}-\mathrm{KH} 550 \mathrm{NPs}$ is higher than unfunctionalized $\mathrm{SiO}_{2}$. This describes the role of the coupling agent (KH550) as a surface modifier to induce additional viscosity retention capacity to the MFomax.

Thus, the viscosity of the MFomax/ $/ \mathrm{SiO}_{2}-\mathrm{KH} 550 \mathrm{NF}$ being the highest viscous NF was further investigated under the influence of pressure (2023 psi) and $125^{\circ} \mathrm{C}$ to depict the

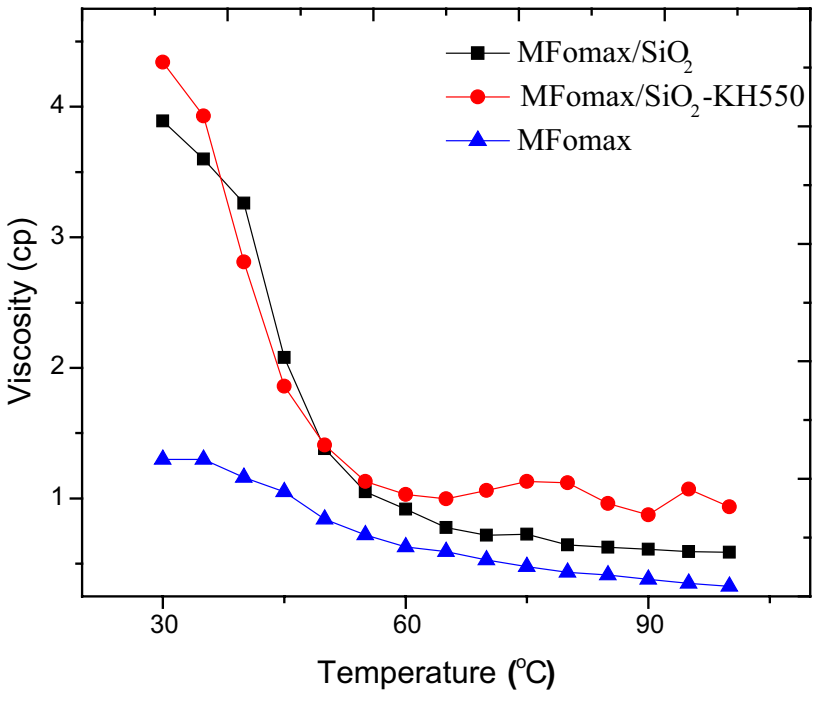

Fig. 6 Temperature effect on the viscosity of the NFs in comparison with the base case MFomax ramped from 30 to $90{ }^{\circ} \mathrm{C}$ at $50 \mathrm{~s}^{-1}$ shear rate

real field conditions. The results in Fig. 7 show that, apart from the effect of temperature, pressure has an additional effect on the viscosity of the MFomax $/ \mathrm{SiO}_{2}-\mathrm{KH} 550$ when compared with the result obtained from Fig. 6. However, minimum viscosity retention is expected to generate quality foam in the porous media.

\section{Spectroscopy characterization studies}

Figure 8 presents the FTIR spectra of the MFomax, MFomax $/ \mathrm{SiO}_{2}$ and $\mathrm{MFomax} / \mathrm{SiO}_{2}-\mathrm{KH} 550$ materials. It can be observed that both the NPs demonstrate chemical interactions with the MFomax due to observed characteristic absorption peaks of $\mathrm{N}-\mathrm{H}\left(3320 \mathrm{~cm}^{-1}\right)$ and $\mathrm{C}=\mathrm{O}$

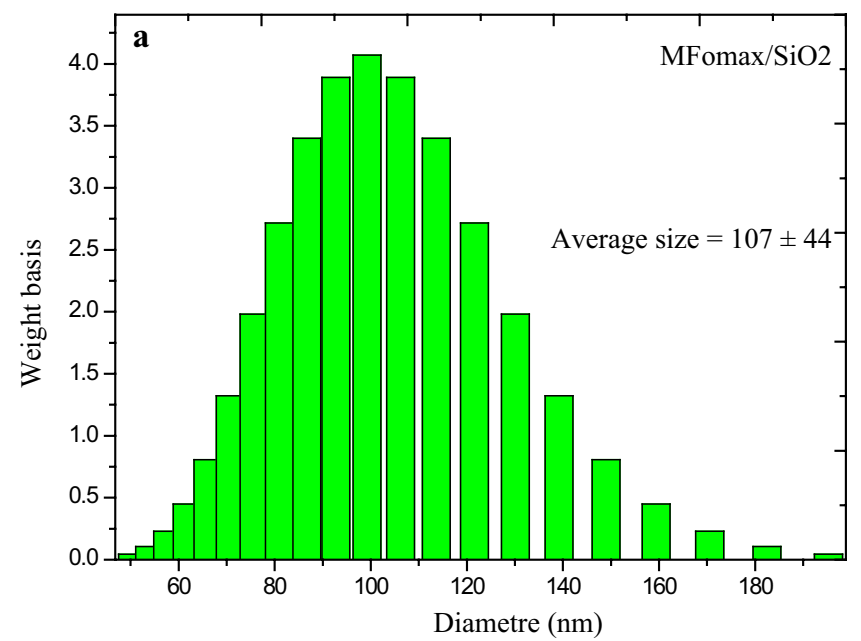

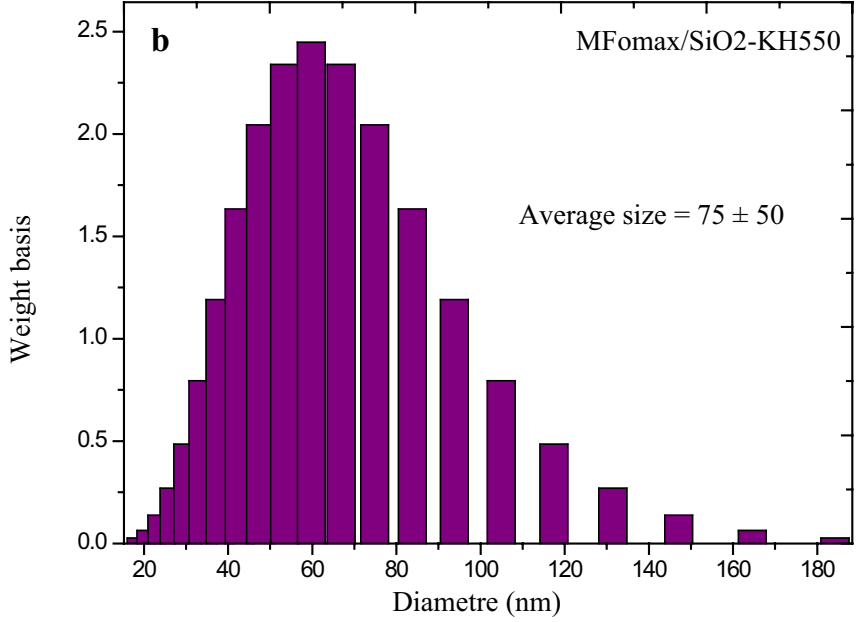

Fig. 5 Particle size distribution and aggregation of the NFs; a MFomax/ $/ \mathrm{SiO}_{2}$ and $\mathbf{b} \mathrm{MFomax} / \mathrm{SiO}_{2}-\mathrm{KH}_{550}$ 


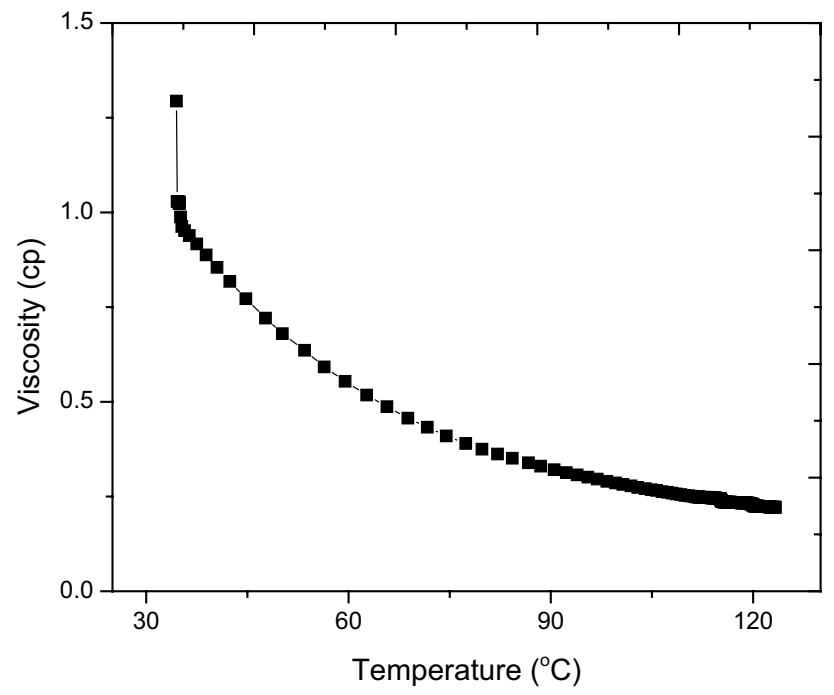

Fig. 7 Influence of pressure and temperature on the viscosity of the MFomax/SiO $2-\mathrm{KH} 550 \mathrm{NF}$ ramped from 30 to $125^{\circ} \mathrm{C}$ and $2023 \mathrm{psi}$

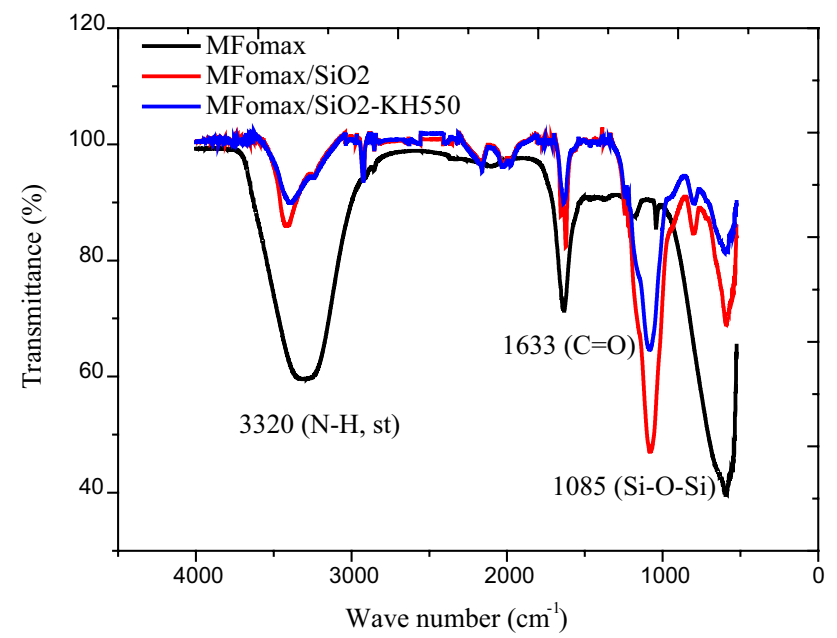

Fig. 8 Comparison of the FTIR spectroscopy between the pure MFomax surfactant and the NF surfactants

$\left(1633 \mathrm{~cm}^{-1}\right)$ from the MFomax and reduction in strong intensities of $\mathrm{Si}-\mathrm{O}-\mathrm{Si}\left(1085 \mathrm{~cm}^{-1}\right)$ in the NFs, respectively; this shows that the NFs constitute the MFomax and the NPs. However, the sharp intensity reduction is more pronounced in the $\mathrm{MFomax} / \mathrm{SiO}_{2}-\mathrm{KH} 550$ spectra due to the binding capacity of the KH550. Similar observations were provided in the work from (Zhu et al. 2014).

The FESEM micrographs of the $\mathrm{SiO}_{2}, \mathrm{SiO}_{2}$-KH550, MFomax $/ \mathrm{SiO}_{2}$ and $\mathrm{MFomax} / \mathrm{SiO}_{2}-\mathrm{KH} 550$ are shown in Fig. 9. From the figures, it can be seen that the mesoporous (amorphous) microstructural properties of both the pure NPs (Fig. 9a, b) transformed into non-mesoporous (c and d), indicating great impact of the MFomax surfactant to change the microstructural properties.

The energy-dispersive X-ray spectroscopy (EDX) conducted on the portion of the FESEM (Fig. 10) reveals the presence of elemental constituents in the NFs. The most important elements being considered in this study are the $\mathrm{Si}$ and $\mathrm{C}$, for bonding capacity. It can be seen that the weight percent (wt\%) of $\mathrm{C}$ was higher in the $\mathrm{MFomax} / \mathrm{SiO}_{2}-\mathrm{KH} 550$ (20.8\%) than in the $\mathrm{MFomax} / \mathrm{SiO}_{2}(15.8 \%)$; this was due to the additional $\mathrm{C}$ from the coupling agent (KH550). However, the Si element, on the contrary, was found to be higher in the MFomax $/ \mathrm{SiO}_{2}$ by about $54 \%$ despite high NPs loading in the $\mathrm{MFomax} / \mathrm{SiO}_{2}-\mathrm{KH} 550$. This observation is believed to be due to the coating effect of the KH550 which reduces the incident beam of X-rays to excite the electrons of $\mathrm{Si}$ that could give many characteristic peaks on the emission spectrum.

The XRD results presented in Fig. 11 show that both the $\mathrm{SiO}_{2}$ and $\mathrm{SiO}_{2}-\mathrm{KH} 550$ exhibited characteristic amorphous nature due to the appearance of broad diffraction shoulders at around $22^{\circ}$ theta, which corresponds to the characteristic nature of the amorphous $\mathrm{SiO}_{2}$ NPs (Pham et al. 2018). However, after the interaction with the MFomax, the transformations of nature from amorphous to crystalline were observed in both the NFs due the appearance of the crystalline peaks in the NFs XRD spectra. But the transformation is more prominent in the $\mathrm{MFomax} / \mathrm{SiO}_{2}-\mathrm{KH} 550$ compared with the $\mathrm{MFomax} / \mathrm{SiO}_{2} \mathrm{NFs}$ because of the binding effect of the KH550 coupling agent.

From the TGA results (Fig. 12), observation shows that MFomax material experiences higher weight loss $(60 \%$ mass loss) than the NFs at around $100{ }^{\circ} \mathrm{C}$ which is due to the evaporation of water in the form of moisture and other smaller molecules. However, with the reinforcement of NPs onto the MFomax, there were significant thermal improvements more than $50 \%$ in each case; this shows that reinforcing the MFomax with the NPs could significantly improve its thermal decomposition resistance due to the thermophysical properties of the NPs.

\section{Coreflooding study; $\Delta p$ buildup assessment}

The coreflood system results are presented in Fig. 13. From the figure, it can be seen that until $6 \mathrm{PV}$, the $\Delta p$ buildup across the core was low $(0.83 \pm 0.3 \mathrm{psi})$; this was due to the water flood at an initial condition. However, after subsequent gas injection (1.1 PV), the $\Delta p$ had increased appreciably ( $\Delta p$ max., $4.39 \mathrm{psi}$ ) indicating the ability of gas to increase $\Delta p$ buildup. Since gas could not make sufficient bubbles in brine has caused $\Delta p$ to drop abruptly leading to early gas breakthrough. This represents the condition of free foam in the core similar to the case reported in the work of Sun et al. 2014. After subsequent fluids injection (MFomax and 
Fig. 9 Comparison of the FESEM micrograph between the pure NPs (a: pure $\mathrm{SiO}_{2}$ and b: pure $\mathrm{SiO}_{2}-\mathrm{KH} 550$ ) and the $\mathrm{NF}$ (c: $\mathrm{MFomax} / \mathrm{SiO}_{2}$ and d: MFomax/ $/ \mathrm{SiO}_{2}-\mathrm{KH} 550$ )
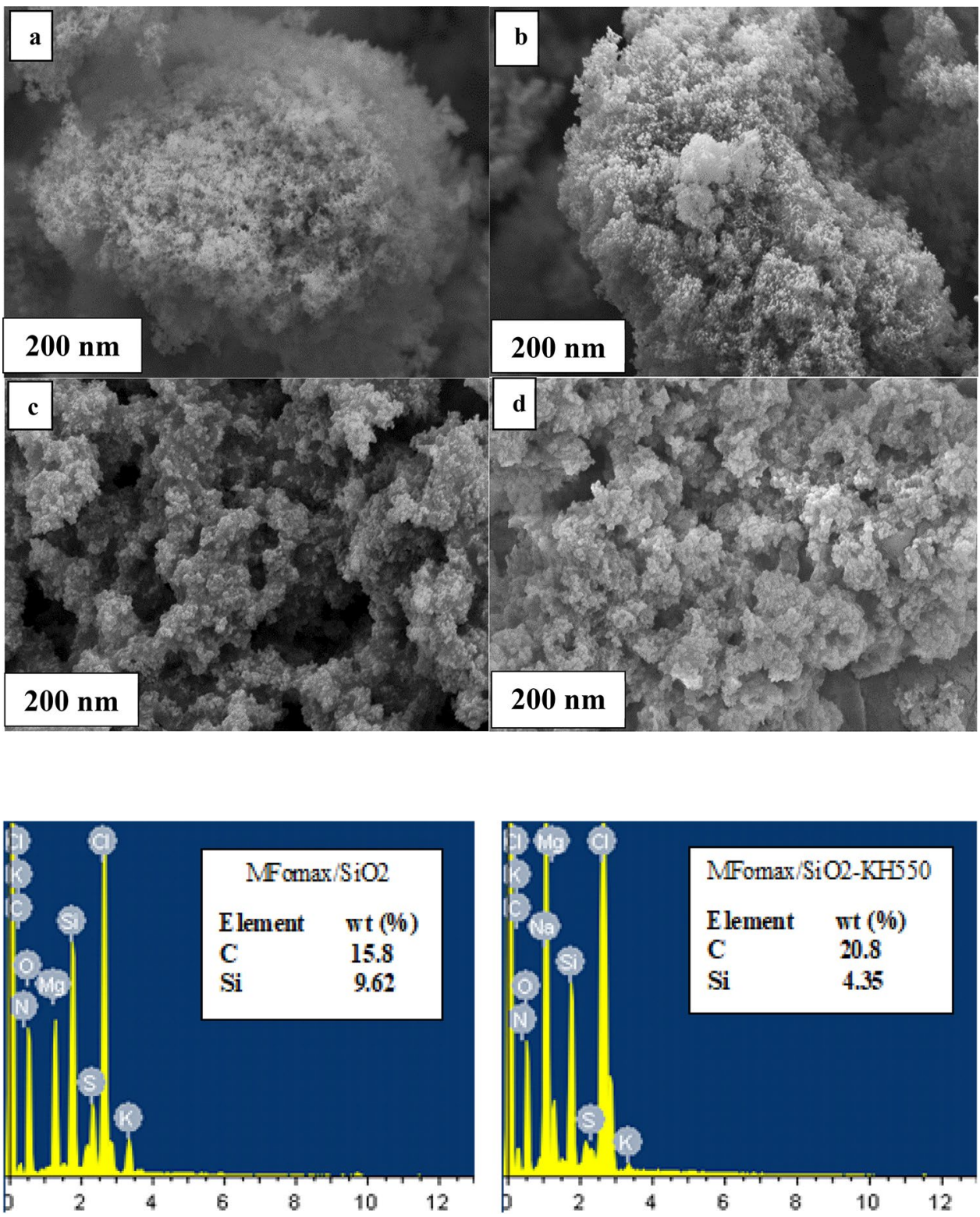

Fig. 10 The EDX spectroscopy showing the elemental composition in the NFs
$\mathrm{MFomax} / \mathrm{SiO}_{2}-\mathrm{KH} 550$ ) to create favorable environment to generate in situ foam, reintroduction of gas into these fluids caused significant $\Delta p$ buildup and high $\Delta p$ peak values were observed for both cases. The $\Delta p$ buildup increase suggests that in situ foams have been generated which immobilized the gas and caused diversion to other sections of the core. The foam can trigger effective pressure buildup better than that of water and gas flooding which is a prerequisite for enhancing oil recovery (Zhao et al. 2015). The main physical mechanism for foam to achieve pressure buildup is usually the influence of Jamin effect, which provides resistance to flow due to contact angle hysteresis of lamellae that bridge the pores. The other mechanism is through complete encapsulation of bubbles by liquid which can easily adapt to shapes at pore throats and block the gas flow (Sun et al.
2016). The average $\Delta p$ buildup due to the $\mathrm{MFomax} / \mathrm{SiO}_{2}$ KH550 NF foam shows that NF foam built more $\Delta p$ having average value of 46 psi as against 25 psi from the precursor MFomax foam. This could be correlated owing to the improved viscosity due the presence of $\mathrm{SiO}_{2}-\mathrm{KH} 550 \mathrm{NPs}$ which enabled the generation of high-quality foam as well as provide a steric barrier to film rupture. Consequently, the $\Delta p$ buildup improvement due to the presence of the NPs is improved by about $83 \%$ relative to the precursor MFomax foam. This finding is in accordance with the work in (Farhadi et al. 2016), where the authors reported that foamcontaining NPs control gas mobility better than its precursor surfactant foam. The effects of NPs blend in surfactant recipes have also been reported in (Vatanparast et al. 2017; Hamza et al. 2017a, b; Farhadi et al. 2016; Soleimani et al. 

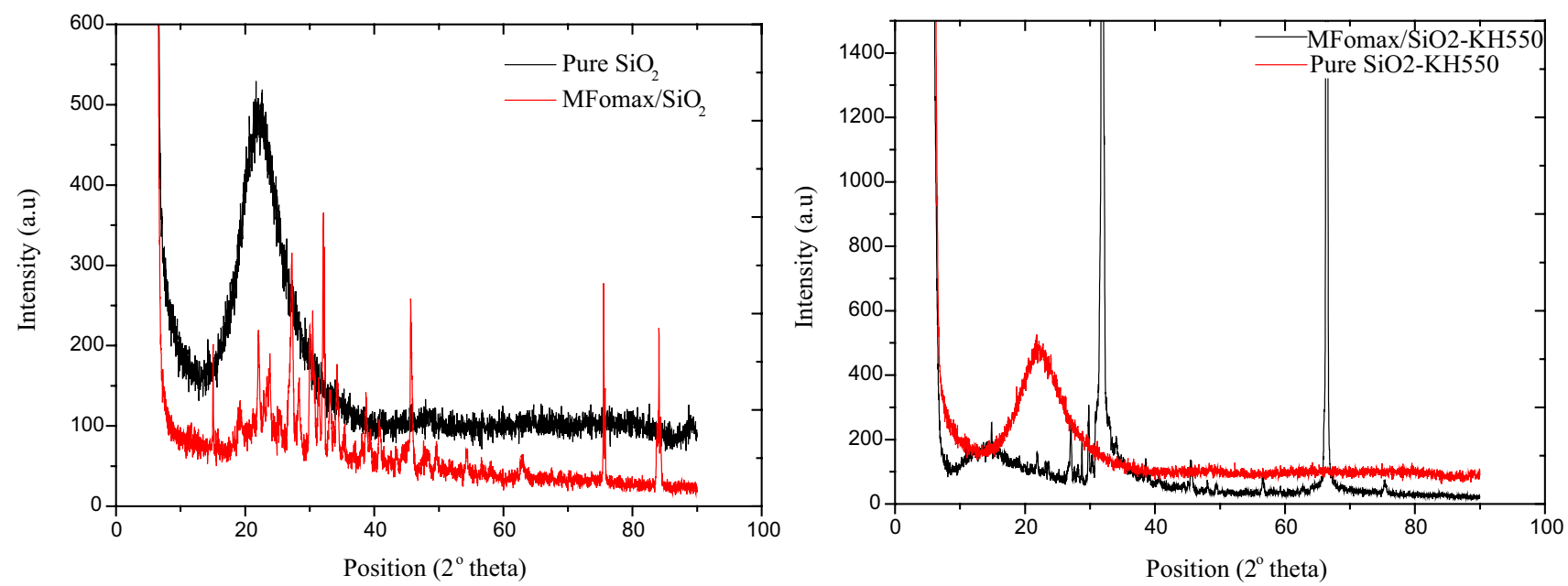

Fig. 11 Comparison of the XRD spectroscopic of the pure NPs and the NFs materials

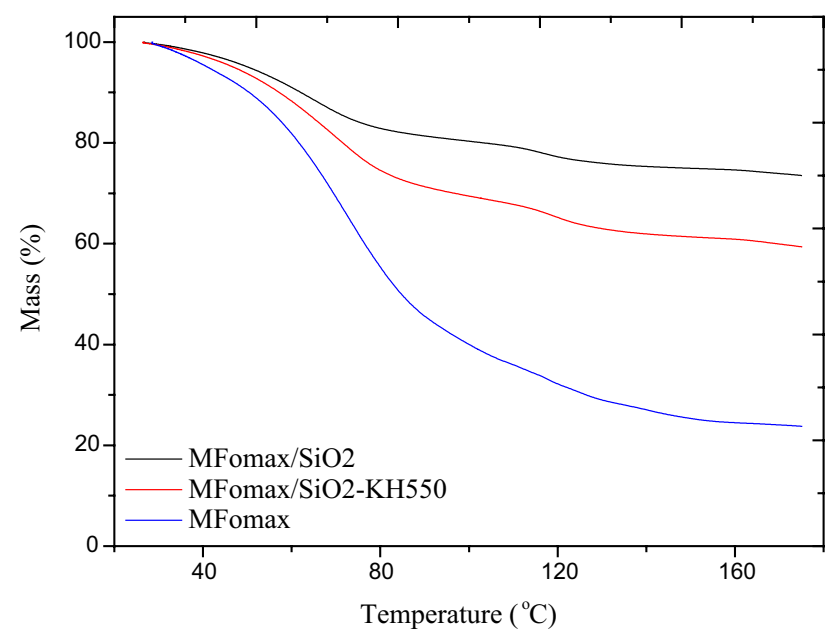

Fig. 12 The thermogravimetric stability of the NFs in comparison with the base case MFomax

2016a, b; Li et al. 2013). The examination of the permeability impairment shows that the injection of the NF reduced the core's permeability by a factor of $8 \%$ which is relatively low and will not affect the reservoir productivity.

\section{Conclusion}

The effects of functionalized and unfunctionalized $\mathrm{SiO}_{2}$ NPs loading on the viscosity of the MFomax surfactant have been demonstrated, and the regression multivariate viscosity prediction models show the synergy between the NPs and MFomax surfactant. Functionalized NPs can improve the MFomax viscosity better than its counterpart.

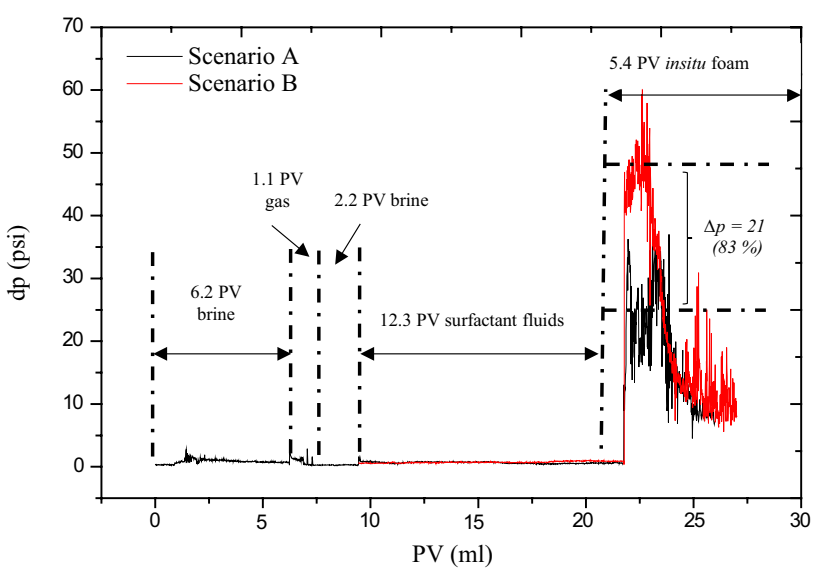

Fig. 13 The $\Delta p$ buildup behavior in the core due to slugs of injection: Scenario A (brine-gas-brine-MFomax surfactant-in situ MFomax foam) and scenario B (nano-fluid surfactant-in situ nano-fluid foam) at $110^{\circ} \mathrm{C}$ and 2023 psi

The high viscous NF surfactant generates quality foam due to high pressure buildup than the precursor MFomax surfactant. Thus, this study recommends the use of the functionalized NPs for efficient pressure buildup as a prerequisite for enhancing oil recovery.

Acknowledgements The authors of this paper have appreciated the support of the project (Grant: PRSB 513CB010) from the PETRONAS Research Sdn, Bhd, and Universiti Teknologi PETRONAS, Malaysia. Also, the Institute of Hydrocarbon Recovery, UTP, and their administrative and technical staff, especially, Mr Iswadi Radzali (Technician, Coreflood system), Mr Muhammad Annas Yahya (Technician, Spectroscopic instruments), Farah Abdul Latif (Research administrator), Nurul Hanis (Research administrator) as well as Mohamed Gamal (Postgraduate researcher) were highly appreciated for their enormous supports in this project. 
Open Access This article is distributed under the terms of the Creative Commons Attribution 4.0 International License (http://creativeco mmons.org/licenses/by/4.0/), which permits unrestricted use, distribution, and reproduction in any medium, provided you give appropriate credit to the original author(s) and the source, provide a link to the Creative Commons license, and indicate if changes were made.

\section{References}

Adenutsi CD, Li Z, Lai F, Hama AE, Aggrey WN (2018) Pore pressure variation at constant confining stress on water-oil and silica nanofluid-oil relative permeability. J Pet Explor Prod Technol 00:1-15. https://doi.org/10.1007/s13202-018-0605-6

Afolabi RO, Yusuf EO (2019) Nanotechnology and global energy demand: challenges and prospects for a paradigm shift in the oil and gas industry. J Pet Explor Prod Technol 9(2):1423-1441. https ://doi.org/10.1007/s13202-018-0538-0

Agi A, Junin R, Gbonhinbor J, Onyekonwu M (2018) Natural polymer flow behaviour in porous media for enhanced oil recovery applications: a review. J Pet Explor Prod Technol 8(4):1349-1362. https ://doi.org/10.1007/s13202-018-0434-7

Agista M, Guo K, Yu Z (2018) A state-of-the-art review of nanoparticles application in petroleum with a focus on enhanced oil recovery. Appl Sci 8(6):871. https://doi.org/10.3390/app8060871

Ahmadi MA, Shadizadeh SR (2013) Induced effect of adding nano silica on adsorption of a natural surfactant onto sandstone rock. Experimental and theoretical study. J Pet Sci Eng 112:239-247. https://doi.org/10.1016/j.petrol.2013.11.010

Al Hinai NM (2017) Experimental study of miscible thickened natural gas injection for enhanced oil recovery. Energy Fuels 31(5):49514965. https://doi.org/10.1021/acs.energyfuels.7b00314

Al Yousef ZA, Almobarky MA, Schechter DS (2019) Surfactant and a mixture of surfactant and nanoparticles to stabilize $\mathrm{CO}_{2}$ /brine foam, control gas mobility, and enhance oil recovery. J Pet Explor Prod Technol. https://doi.org/10.1007/s13202-019-0695-9

Almeida DG, Silva RC, Luna JM, Rufino RD, Santos VA, Sarubbo LA (2017) Response surface methodology for optimizing the production of biosurfactant by candida tropicalis on industrial waste substrates. Front Microbiol. https://doi.org/10.3389/fmicb .2017 .00157

Al-Yousef Z, Almobarky M, Schechter D (2017) Enhancing the stability of foam by the use of nanoparticles. Energy Fuels 31(10):10620-10627. https://doi.org/10.1021/acs.energyfuel s. $7 \mathrm{~b} 01697$

Azarshin S, Moghadasi J, Aboosadi Z (2017) Surface functionalization of silica nanoparticles to improve the performance of water flooding in oil wet reservoirs. Energy Explor Exploit 35(6):685-697. https://doi.org/10.1177/0144598717716281

Cheraghian G, Nezhad SSK, Kamari M, Hemmati M, Masihi M, Bazgir S (2015) Effect of nanoclay on improved rheology properties of polyacrylamide solutions used in enhanced oil recovery. J Pet Explor Prod Technol 5(2):189-196. https://doi.org/10.1007/s1320 2-014-0125-y

Choi SK, Son HA, Kim HT, Kim JW (2017) Nanofluid enhanced oil recovery using hydrophobically associative zwitterionic polymercoated silica nanoparticles. Energy Fuels 31(8):7777-7782. https ://doi.org/10.1021/acs.energyfuels.7b00455

Dang C, Nghiem L, Chen Z, Yang C, Bae W (2017) A comprehensive evaluation of alkaline surfactant polymer flooding and hybrid process for enhanced oil recovery. SPE annual technical conference and exhibition. 187132. https://doi.org/10.2118/187132-ms

Farhadi H, Riahi S, Ayatollahi S, Ahmadi H (2016) Experimental study of nanoparticle-surfactant-stabilized $\mathrm{CO}_{2}$ foam: stability and mobility control. Chem Eng Res Des 111:449-460. https:// doi.org/10.1016/j.cherd.2016.05.024

Fuseni AB, AlSofi AM, AlJulaih AH, AlAseeri AA (2018) Development and evaluation of foam-based conformance control for a high-salinity and high-temperature carbonate. J Pet Explor Prod Technol 8(4):1341-1348. https://doi.org/10.1007/s1320 2-018-0431-x

Hakiki F, Maharsi DA, Marhaendrajana T (2015) Surfactant-polymer coreflood simulation and uncertainty analysis derived from laboratory study. J Eng Technol Sci 47(6):706-725. https://doi. org/10.5614/2Fj.eng.technol.sci.2015.47.6.9

Hamza MF, Sinnathambi CM, Merican ZA (2017a) Recent advancement of hybrid materials used in chemical enhanced oil recovery (CEOR): a review. IOP Conf Ser Mater Sci Eng 206:012007. https ://doi.org/10.1088/1757-899X/206/1/012007

Hamza MF, Sinnathambi CM, Merican ZMA, Soleimani H, Karl SD (2017b) An overview of the present stability and performance of EOR-foam. Sains Malays 46(9):1641-1650. https://doi. org/10.17576/jsm-2017-4609-37

Hanamertani AS, Pilus RM, Manan NA, Mutalib MIA (2018) The use of ionic liquids as additive to stabilize surfactant foam for mobility control application. J Pet Sci Eng 167:192-201. https://doi. org/10.1016/j.petrol.2018.04.010

Hendraningrat L, Torsæter O (2016) A study of water chemistry extends the benefits of using silica-based nanoparticles on enhanced oil recovery. Appl Nanosci 6(1):83-95. https://doi. org/10.1007/s13204-015-0411-0

Hendraningrat L, Zhang J (2015) Polymeric nanospheres as a displacement fluid in enhanced oil recovery. Appl Nanosci 5(8):1009_ 1016. https://doi.org/10.1007/s13204-014-0399-x

Hendraningrat L, Li S, Torsæter O (2013) A coreflood investigation of nanofluid enhanced oil recovery. J Pet Sci Eng 111:128-138. https://doi.org/10.1016/j.petrol.2013.07.003

Jackson SJ, Power H, Giddings D (2017) Immiscible thermo-viscous fingering in Hele-Shaw cells. Comput Fluids 156:621-641. https ://doi.org/10.1016/j.compfluid.2017.04.004

Jamaloei Y, Kharrat BR, Torabi F (2010) Analysis and correlations of viscous fingering in low-tension polymer flooding in heavy oil reservoirs. Energy Fuels 24(12):6384-6392. https://doi.org/10.1021/ ef101061b

Jamaloei Y, Kharrat BR, Torabi F (2011) A mechanistic analysis of viscous fingering in low-tension polymer flooding in heavy-oil reservoirs. J Pet Sci Eng 78(2):228-232. https://doi.org/10.1016/j. petrol.2011.07.011

Jamaloei B, Babolmorad R, Kharrat R (2016) Correlations of viscous fingering in heavy oil waterflooding. Fuel 179:97-102. https://doi. org/10.1016/j.fuel.2016.03.064

Jia H, Yin SP, Ma XP (2017) Enhanced oil recovery mechanism of low oxygen air injection in high water cut reservoir. J Pet Explor Prod Technol 2017:1-7. https://doi.org/10.1007/s13202-017-0389-0

Kamal MS, Hussein AI, Sultan AS (2017) Review on surfactant flooding: phase behavior, retention, IFT, and field applications. Energy Fuels 31(8):7701-7720. https://doi.org/10.1021/acs.energyfuel s. $7 \mathrm{~b} 00353$

Kean Chuan L, Zulhilmi Akmal bin S, Hassan S, Mohd ZH, Beh Hoe $\mathrm{G}$ et al (2016) Effect of zinc oxide nanoparticle sizes on viscosity of nanofluid for application in enhanced oil recovery. J Nano Res. https://doi.org/10.4028/www.scientific.net/JNanoR.38.36

Koca HD, Doganay S, Turgut A, Tavman IH, Saidur R, Mahbubul IM (2017) Effect of particle size on the viscosity of nanofluids: a review. Renew Sustain Energy Rev. https://doi.org/10.1016/j. rser.2017.07.016

Li S, Hendraningrat L, Torsaeter O (2013) Improved oil recovery by hydrophilic silica nanoparticles suspension: 2 phase flow experimental studies. IPTC 2013: international petroleum technology conference. https://doi.org/10.2523/iptc-16707-ms

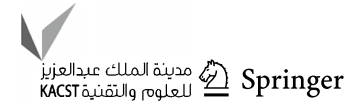


Memon MK, Shuker MT, Elraies KA (2017) Study of blended surfactants to generate stable foam in presence of crude oil for gas mobility control. J Pet Explor Prod Technol 7(1):77-85. https:// doi.org/10.1007/s13202-016-0243-9

Moradi S, Isari AA, Bachari Z, Mahmoodi H (2019) Combination of a new natural surfactant and smart water injection for enhanced oil recovery in carbonate rock: synergic impacts of active ions and natural surfactant concentration. J Pet Sci Eng. https://doi. org/10.1016/j.petrol.2019.01.043

Nasr NH, Mahmood SM, Hematpur H (2019a) A rigorous approach to analyze bulk and coreflood foam screening tests. J Pet Explor Prod Technol 9(2):809-822. https://doi.org/10.1007/s1320 2-018-0545-1

Nasr NH, Mahmood SM, Akbari S, Hematpur H (2019b) A comparison of foam stability at varying salinities and surfactant concentrations using bulk foam tests and sandpack flooding. J Pet Explor Prod Technol. https://doi.org/10.1007/s13202-019-0707-9

Pham T, Bui TT, Nguyen VT et al (2018) Adsorption of polyelectrolyte onto nanosilica synthesized from rice husk: characteristics, mechanisms, and application for antibiotic removal. Polymers 10(2):220. https://doi.org/10.3390/polym 10020220

Pozhar LA (2000) Structure and dynamics of nanofluids: theory and simulations to calculate viscosity. Phys Rev E 61(2):1432. https ://doi.org/10.1103/PhysRevE.61.1432

Protsak I, Pakhlov E, Tertykh V, Le ZC, Dong WA (2018) New route for preparation of hydrophobic silica nanoparticles using a mixture of poly(dimethylsiloxane) and diethyl carbonate. Polymers 10(2):116. https://doi.org/10.3390/polym10020116

Rellegadla S, Prajapat G, Agrawal A (2017) Polymers for enhanced oil recovery: fundamentals and selection criteria. Appl Microbiol Biotechnol 101(11):4387-4402. https://doi.org/10.1007/s0025 3-017-8307-4

Sharma T, Sangwai JS (2017) Silica nanofluids in polyacrylamide with and without surfactant: viscosity, surface tension, and interfacial tension with liquid paraffin. J Pet Sci Eng 152:575. https://doi. org/10.1016/j.petrol.2017.01.039

Soleimani H, Yahya N, Baig MK, Khodapanah L, Sobet M, Burda $M$ et al (2015) Synthesis of carbon nanotubes for oil-water interfacial tension reduction. Oil Gas Res 1:104. https://doi. org/10.4172/2472-0518.1000104

Soleimani H, Ahmad NR, Yahya N, Sabet M, Khodapanah L, Kozlowski G, Chuan LK, Guan BH (2016a) Synthesis and characterization of yttrium iron garnet (YIG) nanoparticles activated by electromagnetic wave in enhanced oil recovery. J Nano Res. https://doi.org/10.4028/www.scientific.net/JNanoR.38.40

Soleimani H, Yahya N, Baig M, Khodapanah L et al (2016b) Catalytic effect of zinc oxide nanoparticles on oil-water interfacial tension. Dig J Nanomater Biostruct 11(1):263-269
Speight JG (2016) Introduction to enhanced recovery methods for heavy oil and tar sands. Gulf Professional Publishing, Houston, pp 353-403. https://doi.org/10.1016/B978-0-12-849906-1.00008-4

Sun Q, Li Z, Li S, Jiang L, Wang J, Wang P (2014) Utilization of surfactant-stabilized foam for enhanced oil recovery by adding nanoparticles. Energy Fuels 28(4):2384-2394. https://doi. org/10.1021/ef402453b

Sun Q, Zhang N, Li Z, Wang Y (2016) Nanoparticle-stabilized foam for effective displacement in porous media and enhanced oil recovery. Energy Technol 4(9):1053-1063

Susheel K (2015) Organic-inorganic hybrid nanomaterials. Springer, Berlin, p 10. https://doi.org/10.1007/978-3-319-13593-9

Vatanparast H, Samiee A, Bahramian A, Javadi A (2017) Surface behavior of hydrophilic silica nanoparticle-SDS surfactant solutions: I. Effect of nanoparticle concentration on foamability and foam stability. Colloids Surf A 513:430-441. https://doi. org/10.1016/j.colsurfa.2016.11.012

Worthen AJ, Bryant SL, Huh C, Johnston KP (2013) Carbon dioxidein-water foams stabilized with nanoparticles and surfactant acting in synergy. AIChE J 59(9):3490-3501. https://doi.org/10.1002/ aic. 14124

Xu MH, Cao YY, Gao SG (2015) Surface modification of nanosilica with silane coupling agent. Key Eng Mater. https://doi. org/10.4028/www.scientific.net/KEM.636.23

Xu F, Kim J, Lee S (2016) Particle-induced viscous fingering. J Non Newt Fluid Mech 238:92-99. https://doi.org/10.1016/j.jnnfm .2016 .06 .014

Zallaghi M, Kharrat R, Hashemi A (2018) Improving the microscopic sweep efficiency of water flooding using silica nanoparticles. J Pet Explor Prod Technol 8(1):259-269. https://doi.org/10.1007/ s13202-017-0347-x

Zhang T, Espinosa D, Yoon KY et al (2011) Engineered nanoparticles as harsh-condition emulsion and foam stabilizers and as novel sensors. Houston, Texas, USA offshore technology conference https://doi.org/10.4043/21212-ms

Zhao G, Dai C, Zhang Y, Chen A, Yan Z, Zhao M (2015) Enhanced foam stability by adding comb polymer gel for in-depth profile control in high temperature reservoirs. Colloids Surf A 482:115-124

Zhu D, Wei L, Wang B, Feng Y (2014) Aqueous hybrids of silica nanoparticles and hydrophobically associating hydrolyzed polyacrylamide used for EOR in high-temperature and high-salinity reservoirs. Energies 7(6):3858-3871. https://doi.org/10.3390/ en7063858

Publisher's Note Springer Nature remains neutral with regard to jurisdictional claims in published maps and institutional affiliations. 